\title{
THE ROLE OF CSR IN THE PROTECTION OF THE EMPLOYEES
}

\author{
Gábor Mélypataki \\ assistant professor, University of Miskolc, Institute of Private Law \\ Department of Agriculture and Labour Law \\ 3515 Miskolc, Miskolc-Egyetemváros, e-mail: jogmega@uni-miskolc.hu
}

\begin{abstract}
Workers are classically the more vulnerable party in employment relationships. Counterbalancing this is one of the tasks of labour law. However, there are also situations where the legal framework alone is not sufficient. In order to maintain or increase the level of protection, it is necessary to have, in addition to legal rules, specific ethical self-regulation by employers. One form of this is CSR. In our opinion, CSR should not only have an impact on persons outside the organisation, but also on employees.
\end{abstract}

Keywords: protection of employees, Corporate Social Responsibility

\section{Introduction}

The situation of workers has changed a lot in recent decades. The subordination that is a classic feature of the employment relationship has been much reduced, but the status of the vulnerable has remained. The law has tried to strengthen the position of workers through its means in recent times. The right to work, as enshrined in national constitutions, and the labour codes of each country, have been instrumental in this. Workers' rights have been raised to a high level in many countries of the world in the present social context. In many places, however, this has only led to temporary solutions. The enforcement of labour rights is affected by many factors.

However, there are not only hard law instruments for enforcing workers' rights but also soft law and ethical solutions. Not all of the effects on workers' rights are defined in law. In many cases, the employer's image of the company and the corporate culture it has developed are also influencing factors. The question is how the employer perceives its role in the employment relationship with the employee. To what extent does the implementation of a relationship system based on classical hierarchical principles seem to be its way of doing things? The only reason why an employer who adheres to classical principles is not bad is that it is more difficult to incorporate innovations into its own corporate culture. The main powers of the employer are to direct, instruct and control. However, social care now seems increasingly inescapable. Social care has become a core value in Western European corporate culture, but it is also increasingly being put into practice in the domestic environment.

Corporate Social Responsibility (CSR), and in the public sector the latest version of it, Public Social Responsibility (PSR), builds on the theory of social care (Jakab \& Ráczi, 2019). CSR is simply defined as the integration of stakeholder values and interests into business operations (Braun, 2015). CSR can be defined as the caring attitude of the employer beyond its statutory obligations. A kind of higher social sensitivity, which is not only expressed in the form of social measures based on charity and, to a large extent, not on PR activities. In today's Hungarian economy, external CSR is best known as a form of social and/or community programme whereby a company's employees help people in 
their environment. However, there is a less known internal side of CSR, which is aimed at employees and which cannot be dissociated from the employer-employee relationship, but goes beyond it to a certain extent. We are not necessarily talking here about a deepening of personal relations, but rather about a certain development of the relationship of trust and confidence along social lines.

Volunteering is also a central element of the definition set out in the European Commission's Green Paper on the framework conditions for CSR. We will see later that this is both an advantage and a disadvantage. CSR as an activity is therefore not mandatory. As a rule, such behaviour and the application of company policy cannot be held accountable. However, it is worth bearing in mind that it is an expectation in today's economic climate, especially in the EU social context. This is also reflected in the fact that the Commission considers CSR to be a fundamental concept. It is a fundamental concept that helps companies to integrate social and environmental issues voluntarily into their business activities and their relations with stakeholders (Suhajda, 2019).

The question arises as to how, if CSR is primarily a reflection of events in the world outside the company, how do we focus our research on employees. To do this, we also had to look at other concepts related to CSR. Stakeholders are those individuals or groups who are or may be affected by the company's operations, whether or not they are aware of this involvement. The group of stakeholders can be divided into internal and external stakeholders from the company's point of view. This means, in our view, that CSR can be distinguished between internal and external depending on the policy being adopted. The main stakeholder groups are therefore the employees and the owner in the internal framework; in the external framework, elements such as trade unions, consumers, the media or investors appear. From this grouping, we have highlighted the employees.

\section{CSR in the Labour Law Relations}

The role of CSR in the field of employment is to strengthen the rules that protect workers. Workrelated responsibility is a form of internal CSR. It is interesting to place it in the context of the many different forms of liability that already exist in employment relationships. In the relationship between the parties, we can talk about liability under employment law, whereby if one party causes damage to the other, it is obliged to compensate for it. This rule also applies to damages caused by an employer (Kenderes \& Rácz, 2018). This is private liability between the parties. Building on this, or even in addition to it, we need to talk about occupational safety and health liability, under which, if the employer predominantly fails to comply with/ensure safe working conditions that do not endanger health, he is liable on an objective basis, from which his possibility of exemption is very limited (Jakab \& Mélypataki, 2018). Building on the above, we can talk about liability issues in the context of social security, which may take the form of a claim for reimbursement. (Tóth, 2018)

In the case of corporate social responsibility, we can highlight the caring attitude of the employer beyond its statutory obligations. A kind of higher social sensitivity, which takes the form of social measures that are not based on goodwill and are not, to a large extent, based on PR activities. In today's Hungarian economy, external CSR is best known as a form of social and/or community programme in which a company's employees help people in their environment. However, there is an internal side of CSR, less known to the general public, which targets employees (Csapóné Riskó \& Tóth, 2017), which is not independent of the employer-employee relationship but also goes beyond it to a certain extent. We are not necessarily talking here about a deepening of personal relations, but rather about a certain development of the fiduciary relationship along social lines. In particular, it is also possible to discuss the issue of the cafeteria allowance, which is common practice in many places and 
can be granted by the law, but whether this is possible at all in a particular company and how the allowance is filled is also a matter for CSR. But where it may not be possible to provide fringe benefits, a positive change in other working conditions may also be effective. The Hungarian Labour Code flexibly defines quite many working conditions.

You don't necessarily need to think about decisions that involve big organisational changes. Often small flexibility in working conditions, especially working hours, is enough. Many good practices relate to changes in the organisation of working time. The use of a time frame not only makes it possible to organise work in the interests of the employer but can also be a way of taking maximum account of the interests of the employee. A good example of this is the Borsod county company which has introduced working hours of 4 days a week and 10 hours a day instead of the usual 5 working days a week and 8 hours a day (Máté, 2020). According to the employer, one of the benefits of the reorganisation of working hours is that employees are less stressed because they have Fridays off in addition to the weekend, so they can take care of the things and issues that used to require them to take time off. On the other hand, the employee can also spend more time with his/her family overall, so this measure helps to balance work and family life. In addition, the company has become more efficient and has made more profit since the measures were introduced.

A similar, yet slightly different solution is being tried by informatics company Rheingans Digital Enabler. As a trial, the company has introduced the shorter full-time working hours also known in Hungarian Mt. According to the company manager, the first five hours of work should be actively used anyway. The rest of the 8-hour working week does not produce any product. These so-called breaks do not, in his opinion, lead to recharging. Another rule is that workers must leave their phones in their bags and only check company email twice. However, after 5 hours, workers can go home or go about their daily business. The majority of workers were positive about the new working arrangements, with some having a new hobby and others reporting a more active social life.

\section{Human rights in the context of employment relationships}

However, in some cases, labour issues still only lead to external CSR. Such cases occur when it is necessary to examine them in parallel with human rights or environmental protection. The emphasis on human rights is also important because multinational companies carry out part of their production in third world countries. In these countries, the enforcement of fundamental and human rights is not very marked. The workers here are even more so, and in many cases, companies are also the beneficiaries of the exploitation of people without real legal and social protection. They gain cheap labour and low production costs. The factories concerned are usually located in China or South-East Asia, or less often in Africa.

The world's most famous brands have been repeatedly linked to human rights abuses. It has been alleged that these companies are aware of the conditions under which their products are made or the raw materials sourced in third world countries. Nestlé has repeatedly come under the spotlight, but Nike and GAP have also been accused of using child labour in their factories in poor countries. These companies have set up industry-wide monitoring systems. These systems are increasingly necessary. Of course, respect for and enforcement of human rights is necessary not only in the countries indicated but everywhere. However, the question is not easy to answer, nor is it always possible to do so using hard law. A good example is the US Supreme Court ruling of October 2020. The judges found that it had not been proven that child labour decisions were made in the US. Accordingly, Nestlé was acquitted. The case started in 2005 when 6 former child workers brought a case against the company. How- 
ever, the judgment does not in itself remove the company's liability and its obligation to take firm action against child labour. Although the court has excluded pecuniary compensation, in our view this does not mean that social responsibility is excluded. After all, it is based on ethical grounds and is different from material compensation. (NESTLE USA, INC. v. DOE ET AL. , 2020)

The adoption and monitoring of human rights-based indicators at the company level is key to the effective follow-up of due diligence and responses to identified human rights impacts. Companies should consider both qualitative and quantitative human rights indicators, incorporating feedback from internal and external sources (including external experts, industry groups and stakeholders where possible).

\section{Summary}

Of course, the impact of the pandemic is not only a change in the working conditions, but it is perhaps here that it has its greatest and most drastic impact. The negative consequence of the Just in Time (JIT) type management system is that the immediate cancellation of orders due to the pandemic leads to a halt in production of new products, which in turn leads to the termination of the factory workers' contracts. Decision-makers have therefore asked multinational companies to show their commitment and behave as socially responsible companies. They should not just do so because factories and workers need them. This behaviour should also be motivated by the fact that these factories (and workers) will be in great demand in the future when the economy restarts (ter Haar, 2021).

It follows from the above that the directions of responsibility in the new employment context are being completely transformed, both at the global level and at the local level. The difference lies in the way the framework is filled. This is because different problems arise in the local labour market than in the case of outsourcing production to third world countries. Businesses have to deal with issues that are difficult to grasp in the legal conceptual framework (being a non-legal concept). They can be made tangible to the law by employing tools outside the law.

\section{Acknowledgement}

The described study was carried out in the framework of the " $\mathrm{K} 120158, \mathrm{~K} \_16$ " researching theme study called "The position of the more vulnerable party in employment relationships in the light of European and Hungarian regulation' " supported by the National Research, Development and Innovation Office.

\section{References}

[1] Braun, R. (2015). Vállalati társadalmi felelösségvállalás - A vállalatok politikája. Budapest, Akadémiai Kiadó. https://doi.org/10.1556/9789630597623

[2] Csapóné Riskó, T., Tóth, E. (2017). Vállalati felelősség - alkalmazottakat célzó belső. Jelenkori társadalmi és gazdasági folyamatok, 12(4), 207-218. https://doi.org/10.14232/jtgf.2017.4.207-218

[3] Jakab, N., Mélypataki, G. (2018). A munkavédelmi törvény alapján fennálló felelősség magyarázata. In J. Barta, T. Barzó, \& C. Csilla (szerk.), Magyarázat a kártéritési jogról (pp. 506-533). Budapest, Wolters Kluwer.

[4] Jakab, N., \& Ráczi, Z. (2019). Issues of Public Social Responsibility in Great Britain and Hungary. Zbornik Radova Pravni Fakultet (Novi Sad), 53(2), 603-611. https://doi.org/10.5937/zrpfns53-22780 
[5] Kenderes, G., Rácz, Z. (2018). A munkajogi kárfelelősség magyarázata. In J. Barta, T. Barzó, \& C. Csák (szerk.), Magyarázat a kártéritési jogról (pp. 446-505). Budapest, Wolters Kluwer.

[6] Máté, D. A. (2020). 6 óra munka, 9 óra pihenés, 9 óra szórakozás: A 30 órás munkahét nyomában. Erdélyi Jogélet, 1(3), 77-93. https://doi.org/10.47745/ERJOG.2020.04.07

[7] Nestle USA, Inc. V. Doe et al. (Supreme Court 2020. October).

[8] Suhajda, A. (2019). CSR - Vállalati társadalmi felelősségvállalás. In B. A. Ágnes (Szerk.), A társadalmi közfelelösség alapjai. Budapest, Nemzeti Közszolgálati Egyetem.

[9] ter Haar, B. P. (2021). Corporate social responsibility in times of the COVID-19 pandemic. Problematyki Prawa Pracy i Polityki Socjalnej, 19(2), 1-31. https://doi.org/10.31261/zpppips.2021.19.01

[10] Tóth, H. (2018). Megtérítési igény az egészségbiztosítási ellátások és nyugellátások körében. In J. Barta, T. Barzó, \& C. Csilla (szerk.), Magyarázat a kártéritési jogról (pp. 534-562). Budapest, Wolters Kluwer. 